\title{
The Determinant Effect of Self-Talk Status of Athletes on Life Satisfaction
}

\author{
Hüdaverdi Mamak \\ ${ }^{1}$ School of Physical Education and Sports, Niğde Ömer Halisdemir University, 51700, Niğde, Turkey \\ Correspondence: Hüdaverdi Mamak, School of Physical Education and Sports, Niğde Ömer Halisdemir \\ University, 51700, Niğde, Turkey. E-mail: hmamak@ohu.edu.tr
}

Received: June 3, 2019

Accepted: June 28, 2019 Online Published: July 12, 2019

doi:10.5539/jel.v8n4p161

URL: https://doi.org/10.5539/jel.v8n4p161

\begin{abstract}
The main purpose of this research is to examine the effect of athletes' self-talk over their life satisfaction. One hundred-sixteen females (age $=24.40 \pm 3.65$ year) and 200 males (age $=25.28 \pm 3.47$ year) voluntarily participated in this research. The sample of the research consists of athletes who were in different branches and have different levels of sportiveness degree and history. In this research, information about socio-demographic variables was collected by Personal Information Form which was composed by the researcher. "Self-talk Questionnaire" and "Life Satisfaction Scale" were used to reveal individual differences between the study's variables. In the analysis of the data descriptive statistical methods and in independence examples T-test and Multiple Stepwise Regression Analysis methods were used. In the result of the present research, in addition to obtained conclusion that self-talk levels of athletes are a predictor of life satisfaction, it has been observed that self talk levels of athletes differ from each other regarding gender variable $(p<0.05)$. Also, it has been observed that the life satisfaction levels of athletes differ in terms of gender variable $(p<0.05)$. As a result, it has been thought that the relationship between life satisfaction and motivational and cognitive self-talk can be explained by self-determination theory.
\end{abstract}

Keywords: quality of life, sports, talking to ourselves

\section{Introduction}

Nowadays, objectives of people are having a life in quality and happiness. A human as an individual who wants to fit happiness into the limited lifetime keeps on this searching in society. In this searching process, talking to oneself, which has the possibility of taking place frequently in each individual's daily life, has come across us in sports environments as the main situation that individual may experience frequently. In order to be happy for the individual, it is a situation that the positive or negative process of talking to oneself will be determinant. Just like in normal life period, positive or negative talks can be effective in the general psychological situations of individuals who talk cognitively or motivationally to themselves.

In our daily life, talking to ourselves is known as a profoundly natural activity (Bayköse, 2018). This behavior that we are often in plays an active role in shaping our feelings and thoughts (Morrin, 1993). There are two separate functions of talking to oneself as cognitive and motivational (Hardy, 2006). Results obtained from various studies have shown that successful athletes and their coaches use more cognitive strategies than less successful athletes and their coaches (Gould et al., 2002; Gould et al., 1992) and it has been detected that these strategies are effective in increasing general performance (Hanton \& Jones, 1999; Thelwell \& Maynard, 2003). One of the common cognitive strategies used by athletes is self-talk. Self-talk is one of the prominent methods of cognitive and cognitive-behavioral interventions (Conroy \& Metzler, 2004). Our knowledge about self-talk with respect to mental skills is quite limited. It can be said that functionally self-talk behavior is used by researchers in sports sciences field in order to increase performance (Hardy \& Hall, 2005). Furthermore, self-talk may also be related to several psychological situations. One of these is the concept of life satisfaction or life saturation as named by the researchers in our country.

Life satisfaction is defined as a universal evaluation of one's own life by Pivot et al. (1991). Life satisfaction is an evaluation of one's own life, a personal feeling or attitude (Han \& Kim, 2004; Kim, 1982). Life satisfaction which will be associated with individuals' both cognitive and motivational emotion status can be considered as a cognitive component of the state of subjective well-being and a subjective evaluation of one's own life. This 
definition is a result of a cognitive evaluation process and can be seen as a comparison between self-successes and desires (Diener, 1984).

Diener (1984) indicates that life saturation has a dynamic structure which can change according to person's present living conditions and personal standards. Within this context, the conditions of athletes' self-talk also can be related due to the effect on psychological factors determining one's present living conditions and personal standards.

The objective of this research is to find the answer to the question of "Is there a determinant effect of athletes' self-talk upon life satisfaction?" Secondly, in the present research, there will be an attempt to get answers for the question of "Have athletes' life satisfaction and talk levels differed with respect to the level of gender sportiveness and the condition of being a national team athlete?"

\section{Method}

In research, relational screening model was used. Relational screening model is described as a research model which aims to determine the simultaneous change and/or degree between two or more variables (Gay, 1987; Karasar, 1999; Gall, Gall, \& Borg, 1999).

In this research, it is aimed at finding out the determining effect of optimal performance emotion status of athletes in life satisfaction. In this regard, our research has had a relational quality of examination. On the other hand, the comparison of whether optimal performance emotion status of athletes and their life satisfaction differ or not with regards to gender variable has scrutinized by screening model method (Gay, 1987; Karasar, 1999; Gall et al., 1999). The main reason of using the screening pattern is that the research of screening model makes important contributions to understanding and raising the information, theory, and application (Balc1, 2001).

One hundred and sixteen female (mean age $=24.40 \pm 3.65$ ) and 200 male (mean age $=25.28 \pm 3.47$ ) that make up 316 athletes (mean age $=24.96 \pm 3.55$ ) voluntarily attended this research. The sample of the research consists of athletes who are in different branches and have different levels of sportiveness degree and history. The sports experience of athletes in the present research is $10.87 \pm 5.23$ year.

In this research, information about socio-demographic variables was collected by Personal Information Form which was composed by the researcher. In order to achieve the goal of the research, Self-talk Questionnaire (S-TQ) which was developed by Zervas, Stavrou and Psychountaki (2007) to reveal individual differences in determined dimensions with regard to motivational and cognitive self-talk processes and which was adapted to Turkey by Engür (2011) and "Life Satisfaction Scale" which was developed by Diener, Emmons, Larsen and Griffin (1985) and which was adapted to Turkish culture by Köker (1991) were used.

Information about the scales used in the research is given in subheadings.

The scale's adaptation to Turkey which was developed by Diener et al. (1985) to identify individuals' life saturation levels was implemented by Köker (1991). The scale consists of 5 item including the following statements; "my life is in many aspects close to my goals; my life condition is pretty good; I'm content with my life; up to now I've achieved whatever I wanted to, and if I were reborn I would change almost nothing in my life". Options from 1 to 7 are presented for each item to change between "not appropriate" and "very appropriate". The scale comprises of 5 questions and involves a single sub-dimension. For our research group with respect to life satisfaction scale, Cronbach's Alpha reliability coefficient has been calculated as .81 .

Cronbach's Alpha reliability coefficient frequently used by researchers in terms of reliability is a designation of internal consistency of the items within the assessment instrument. That Cronbach's Alpha reliability coefficient is between .80-.90 emphasizes that assessment instrument is highly reliable (Akgül, 2003; Tavşancıl, 2002).

Self-talk Questionnaire (S-TQ) (Appendix 1) has been developed by Zervas, Stavrou and Psychountaki (2007) to uncover the personal differences in terms of motivational and cognitive self-talk processes at appointed dimensions (Zervas et al., 2007).

The scale consists of 11 items done according to 5 evaluation steps (1 Never, 2 Seldom, 3 Sometimes, 4 Usually, 5 Always) and includes 2 sub-scales. These sub-scales are Motivational Function and Cognitive Function.

In Engür's (2011) study "Motivational Function" in sub-scale, Cronbach Alpha Value is .93. As for Cronbach Alpha Value, an internal consistency coefficient has been found as .87 in "Cognitive Function" sub-scale. Generally, a reliability coefficient of the scale has been identified as .95 .

Personal information form which has been prepared appropriately for the research's objective by the researcher to achieve research's purpose has been set to obtain demographic information about athletes and gather certain information like gender, age, education, whether he/she is national in his/her sports branch, sportiveness level, 
for how many years he/she has been doing the performed sports branch, and how often he/she exercises for the performed sports branch per week.

Scales for this study with the heading of "The effect of optimal performance emotion status of athletes on the life satisfaction" were prepared in an electronic environment and transmitted to participants in an electronic environment. At the beginning of the research form, there is an approval form. After participants confirm the approval form, the actual research form appears. Individuals who did not confirm the approval form were out of the research's scope. All the individuals attending the research were involved voluntarily in the research.

In the analysis of obtained data descriptive statistical methods and in independence examples T-test and Multiple Stepwise Regression Analyses methods were used. Analyses were made in SPSS package program and the meaning level was taken as $\mathrm{p}<0.05$ in the research.

Moreover, the effect values were also examined regarding the analysis that has been done; and the values of Cohen's $d$ and $\eta^{2}$ were checked in the decision phase. In the calculations of effect value, the measurement of effect size calculated according to the difference of ensemble average is shown with Cohen's $d$ (Cohen, 1988), Glass's g (Glass, 1976), and Hedge's d (Hedges, 1981). As for that, the association power measurement calculated according to variation is figured out in terms of the correlation between the independent variable and the dependent variable, and it is stated by the computation of $R^{2}$ and $\eta^{2}$ (Maxwell \& Delaney, 1990; Synder \& Lawson, 1993).

\section{Results}

Table 1. The levels of self-talk and the point mean of life satisfaction of athletes attending the research (SD: Standard deviation).

\begin{tabular}{lllll}
\hline Gender & & Motivational & Cognitive & Life Satisfaction \\
\hline Female & Mean & 4.12 & 4.25 & 4.63 \\
& SD & 0.80 & 0.80 & 1.13 \\
Male & Mean & 3.73 & 3.71 & 4.06 \\
& SD & 1.07 & 1.08 & 1.04 \\
Total & Mean & 3.87 & 3.91 & 4.27 \\
& SD & 1.00 & 1.02 & 1.11 \\
\hline
\end{tabular}

According to Table 1, when the obtained point means were analyzed in self-talk questionnaire of attended athletes while motivational function in sub-dimension was $4.12 \pm 0.80$ for female athletes and $3.73 \pm 1.70$ for male athletes, in cognitive function sub-dimension it has been identified as $4.25 \pm 0.80$ for female athletes and $3.71 \pm 1.08$ for male athletes. When examining life satisfaction, while it was $4.63 \pm 1.13$ for female athletes, for male athletes it was identified as $4.06 \pm 1.04$.

Table 2. Regression analysis results regarding the effect of self-talk levels of athletes on determining their life satisfaction

\begin{tabular}{llll}
\hline & $\beta$ & $\mathrm{T}$ & $\mathrm{p}$ \\
\cline { 2 - 5 } & & $\beta$ & 0.858 \\
Motivational Function & 0.022 & 0.180 & 0.800 \\
\hline
\end{tabular}

Note. $\mathrm{R}=0.401 ; \mathrm{R}^{2}=0.161 ;$ Adjusted $\mathrm{R}^{2}=0.155 ; \mathrm{F}(2,313)=29.968 ; \mathrm{p}=0.000$.

According to multiple stepwise regression analyses, Motivational Function one of self-talk sub-dimensions did not get into the model $(\beta=0.022 ; p>0.05)$. But, according to the results of the analysis, Cognitive Function sub-dimension one of self-talk sub-dimensions got into the model $(\beta=0.417 ; p>0.05)$. According to the results of the analysis, a meaningful relationship has been found out between Cognitive function's sub-dimension scores and life satisfaction points belonging to the athletes $\left(\mathrm{R}=0.40 ; \mathrm{F}_{(2,313)}=29.968 ; \mathrm{p}<0.05\right)$. A meaningful and positive relationship has been found out between Cognitive Function levels, sub-dimension of Self-talk, and life satisfaction $(\beta=0.417 ; p>0.05)$. Cognitive Self-talk points belonging to the athletes explains $\% 16$ of the total variable regarding life satisfaction $\left(R^{2}=0.161 ; p<0.05\right.$; Table 2$)$. 
Table 3. Self-talk and life satisfaction levels according to the gender variable of athletes (SD: Standard deviation)

\begin{tabular}{llllllll}
\hline & Gender & $\mathrm{N}$ & Mean & $\mathrm{SD}$ & $\mathrm{t}$ & $\mathrm{p}$ & $d$ \\
\hline Motivational & Female & 116 & 4.12 & 0.80 & 3.683 & 0.000 & 0.39 \\
& Male & 200 & 3.73 & 1.07 & & & \\
Cognitive & Female & 116 & 4.25 & 0.80 & 4.711 & 0.000 & 0.48 \\
& Male & 200 & 3.71 & 1.08 & & & \\
Life Satisfaction & Female & 116 & 4.63 & 1.13 & 4.495 & 0.000 & 0.54 \\
& Male & 200 & 4.06 & 1.04 & & & \\
\hline
\end{tabular}

There was a significant difference between the levels of athletes' motivational self-talk in the view of gender variable $(\mathrm{p}<0.05)$. In the result of obtained difference, it can be said that female athletes (mean $=4.12$ ) have a higher level of motivational self-talk than male athletes (mean $=3.73$; Table 3 ).

A significant difference was found between the levels of athletes' cognitive self-talk in the view of gender variable $(\mathrm{p}<0.05)$. In the result of obtained difference, it can be said that female athletes (mean $=4.25)$ have a higher level of cognitive self-talk than male athletes (mean $=3.71$ ).

Gender variable was statistically significant between the levels of athletes' life satisfaction $(p<0.05)$. In the result of obtained difference, it can be said that female athletes (mean $=4.63$ ) have a higher level of life satisfaction than male athletes (mean $=4.06)$.

Table 4. Self-talk and life satisfaction levels according to the sportiveness level variable of athletes (SD: Standard deviation).

\begin{tabular}{llllllll}
\hline & Sportiveness Level & $\mathrm{N}$ & Mean & $\mathrm{SD}$ & $\mathrm{t}$ & $\mathrm{p}$ & $\mathrm{d}$ \\
\hline Motivational & Professional & 101 & 4.08 & 0.87 & 2.75 & 0.006 & 0.33 \\
& Amateur & 215 & 3.77 & 1.04 & & & \\
Cognitive & Professional & 101 & 4.17 & 0.87 & 3.16 & 0.002 & 0.39 \\
& Amateur & 215 & 3.79 & 1.07 & & & \\
Life Satisfaction & Professional & 101 & 4.73 & 1.16 & 4.98 & 0.000 & 0.59 \\
& Amateur & 215 & 4.05 & 1.02 & & & \\
\hline
\end{tabular}

A significant difference was found between the levels of athletes' motivational self-talk in the view of sportiveness level variable $(\mathrm{p}<0.05)$. In the result of obtained difference, it can be said that professional athletes $($ mean $=4.06)$ have a higher level of motivational self-talk than amateur athletes (mean $=3.77$; Table 4).

There was a significant difference between the levels of athletes' cognitive self-talk in the view of sportiveness level variable $(\mathrm{p}<0.05)$. In the result of obtained difference, it can be said that professional athletes (mean = 4.17) have a higher level of cognitive self-talk than amateur athletes (mean $=3.79)$.

Sportiveness level was different between the levels of athletes' life satisfaction $(p<0.05)$. In the result of obtained difference, it can be said that professional athletes (mean $=4.73)$ have a higher level of life satisfaction than amateur athletes $($ mean $=4.05)$.

Table 5. Self-talk and life satisfaction levels according to the state of being a national athlete variable (SD: Standard deviation).

\begin{tabular}{llllllll}
\hline & Athletic Level & $\mathrm{N}$ & Mean & $\mathrm{SD}$ & $\mathrm{t}$ & $\mathrm{p}$ & $d$ \\
\hline Motivational & National & 60 & 4.22 & 0.91 & 3.266 & 0.002 & 0.45 \\
& Non-National & 256 & 3.79 & 1.00 & & & \\
Cognitive & National & 60 & 4.20 & 0.89 & 2.747 & 0.007 & 0.38 \\
& Non-National & 256 & 3.84 & 1.04 & & & \\
Life Satisfaction & National & 60 & 4.49 & 1.21 & 1.572 & 0.120 & 0.59 \\
& Non-National & 256 & 4.22 & 1.08 & & & \\
\hline
\end{tabular}

A significant difference was found between the levels of athletes' motivational self-talk in athletic level variable $(p<0.05)$. In the result of obtained difference, it can be said that national athletes (mean $=4.22)$ have a higher level of motivational self-talk than non-national athletes (mean $=3.79$; Table 5). 
There was a significant difference between the levels of athletes' cognitive self-talk in athletic level variable ( $\mathrm{p}<$ 0.05 ). In the result of obtained difference, it can be said that national athletes (mean $=4.20$ ) have a higher level of cognitive self-talk than non-national athletes (mean $=3.84$ ).

Athletic level was different between the levels of athletes' life satisfaction $(p<0.05)$. In the result of obtained difference, it can be said that national athletes $($ mean $=4.49)$ have a higher level of life satisfaction than non-national athletes $($ mean $=4.22)$.

\section{Discussion}

Within the obtained results, in this section, there is the comparison between the results of this research and the studies which appear in the related literature and are included in the scope of the present research's purpose.

When score means that were obtained in self-talk questionnaire from the athletes who attended the research are examined, while motivational function in sub-dimension is for female athletes $4.12 \pm 0.80$ and for male athletes $3.73 \pm 1.70$, cognitive function in sub-dimension is identified as for female athletes $4.25 \pm 0.80$ and for male athletes $3.71 \pm 1.08$. When examined regarding life satisfaction, it has been determined as for female athletes $4.63 \pm 1.13$ and for male athletes $4.06 \pm 1.04$.

In terms of the findings that we had at the end of our study, it can be said that the self-talk status has a descriptive nature related to life condition parallel to the findings gained as the answer to the question of "does the level of athletes' self-talk have a determining effect on life satisfaction?", which is the basic problem of the research. Since the relation between life satisfaction and self-talk is positive and linear, it is thought that when there is an increase of 5 units in an athlete self-talk, then an increase of 1 unit in life satisfaction can be observed. When concerned literature was scrutinized, no research regarding self-talk status as the determinants of life satisfaction in athletes was found. Nevertheless, in the related literature in a research implemented by Yildı, Gülşen and Yilmaz (2015), the optimal performance emotion status was examined as a determinant of life satisfaction, and it has been emphasized that it is a life satisfaction determinant. In other research, Bayköse (2018) outlines that self-talk is a determinant of optimal performance emotion status.

With respect to gender variable, a meaningful discrepancy has been observed statistically between the levels of motivational self-talk of athletes $(\mathrm{p}<0.05)$. In the result of this attained difference, it can be said that female athletes (mean $=4.12$ ) have more level of motivational self-talk than male athletes (mean $=3.73)$. With regards to gender variable, a meaningful discrepancy has been observed statistically between the levels of cognitive self-talk of athletes $(\mathrm{p}<0.05)$. In the result of this attained difference, it can be said that female athletes (mean = 4.25 ) have more level of cognitive self-talk than male athletes (mean $=3.71$ ). Within this context, the results of the research designate an analogy with the findings of a research made by Nergiz, Bayköse and Y1ldiz (2015) on dancers. In a qualitative research made by Gammage, Hardy and Hall (2001), female athletes were compared to male athletes. It revealed that male athletes made more negative talk in the issue of internal self-talk, were more explicit in the issue of external self-talk, and had less latent self-talk than female athletes. In this sense, it may be originated from this situation that self-talk sub-dimensions of male athletes in both have less point mean than female athletes. When related literature is examined, the findings of a research done by Engür (2011) in Turkey is also such as to support our research findings regarding the gender variable. In addition, in the concerned literature the research done by Hardy, Hall and Hardy (2005) it was found that the level of self-talk of athletes did not change with regard to gender variable. Within this context, the findings of Hardy et al. (2005) conflict with our research's findings. Another research contradicting with our research findings in terms of gender variable is the research findings done by Bayköse (2018). In the research done in Turkey by Bayköse (2018) within the scope of in the sample of amateur and professional athletes, it was reported that there is no statistical difference between female and male athletes regarding the gender variable. It was observed that there is statistically a meaningful discrepancy between the levels of life satisfaction of athletes in terms of gender variable $(\mathrm{p}<0.05)$. In the result of this difference, it can be said that compared to male athletes $($ mean $=4.06)$ female athletes (mean $=4.63$ ) has more level of life satisfaction.

With respect to sportiveness level variable, statistically, a meaningful difference has been observed between the levels of motivational self-talk of athletes $(\mathrm{p}<0.05)$. In the result of this difference, it can be written that compared to amateur athletes (mean $=3.77)$ professional athletes $($ mean $=4.06)$ have more level of motivational self-talk. With regard to sportiveness level variable, statistically, a meaningful difference has been observed between the levels of cognitive self-talk of athletes $(p<0.05)$. In the result of this difference, it can be said that compared to amateur athletes $($ mean $=3.79)$ professional athletes $($ mean $=4.17)$ have more level of cognitive self-talk. The discrepancy of sportiveness level parallel to our research on the levels of self-talk and sportiveness level scrutinized within experience variable by Nergiz (2015) caused also a difference in the level of self-talk of 
athletes. When related literature has been searched, a contrast to the obtained findings, Hardy et al. (2005) and Gammage et al. (2001) indicated that there is not any relation between experiences and self-talk. Regarding sportiveness level variable, statistically, a meaningful difference has been observed between the levels of life satisfaction of athletes $(p<0.05)$. In the result of this difference, it can be stated that compared to amateur athletes (mean $=4.05)$ professional athletes $($ mean $=4.73)$ have more level of life satisfaction.

With regard to the condition of being national variable, statistically, a meaningful difference has been observed between the levels of motivational self-talk of athletes $(\mathrm{p}<0.05)$. In the result of this difference, it can be said that compared to non-national athletes $($ mean $=3.79)$ national athletes $($ mean $=4.22)$ have more level of motivational self-talk. With respect to the condition of being national variable, statistically, a meaningful difference has been observed between the levels of cognitive self-talk of athletes $(p<0.05)$. In the result of this difference, it can be stated that compared to non-national athletes $($ mean $=3.84)$ national athletes $($ mean $=4.20)$ have more level of cognitive self-talk. It can be said that in both the level of self-talk sub-dimensions of national athletes, compared to non-national ones, have much higher score mean. With regard to the condition of being national variable, statistically, a meaningful difference has been observed between the levels of life satisfaction of athletes $(\mathrm{p}<0.05)$. In the result of this difference, it can be stated that compared to non-national athletes $($ mean $=4.22)$ national athletes (mean $=4.49)$ have more level of athletes' life satisfaction. In the research done in the related literature regarding these findings, no research was found in terms of athletes' condition of being national. Nonetheless, these findings have been considered that they may be originated from the status they have because of the advantages of athletes' talent.

When the results of the present research have been examined, by investigating theoretical framework in the related literature the relationship between research findings and self-determination theory has attracted attention. The goals of self-determination theory are to identify the conditions procuring a healthy development of individuals, groups, and societies and to describe clearly active factors in the process of growth, union, and well-being (Ryan \& Reci, 2000). In the theory, it has been put emphasis on that humans are active organisms which essentially have a consistent ego, are inclined to psychological development, unite their livings, and try to overcome existing obstacles (Ryan \& Deci, 2000; Deci \& Ryan, 2002). Besides these innate tendencies in shaping individuals' dispositions, the characteristics of their environment which they are situated are also significant. That their present environment supports autonomy provides them to live their emotion of choice and feed their main psychological needs (Deci \& Ryan, 1985; Williams, Frankel, Campbell, \& Deci, 2000; Deci, Ryan, Lronr, Usunov, \& Kornazheva, 2001). Parallel to these data, it has been thought that the relationship between life satisfaction and motivational and cognitive self-talk can be explained by self-determination theory.

\section{Conclusion}

As a result, a research on the constraints indicated in this study and theory-based other studies are utmost important and required. The subject can be clarified by doing experimental and relational studies about self-talk studies in Turkey sample. Lastly, with respect to the situational findings in our sample, the reasons that female athletes' level of self-talk is more motivational and cognitive self-talk compared to male athletes can be examined in future researches.

\section{References}

Akgül, A. (2003). Statistical analyses in medical studies (2nd ed.). Ankara: Emek Ofset Ltd Şti.

Balci, A. (2001). Sosyal bilimlerde araştırmalar. Ankara: Pegem A Yayıncılık.

Bayköse, N. (2018). Sporcularda kendi kendine konuşma, görüntü, optimum performans. LAP LAMBERT Akademik Yayıncilik.

Conroy, D., \& Metzler, D. (2004). Farklı rekabetçi kaygı biçimleriyle ilişkili olan kendi kendine konuşma kalıpları. Spor ve Egzersiz Psikolojisi Dergisi, 26, 69-89. https://doi.org/10.1123/jsep.26.1.69

Deci, E., \& Ryan, R. (1985). Genel Nedensellik Yönelimleri Ölçeği: Kişilikte kendini belirleme. Kişilik Araştırma Dergisi, 19, 109-134. https://doi.org/10.1016/0092-6566(85)90023-6

Deci, E., \& Ryan, R. (2000). Hedefin "neyi” ve "niçini” izliyor: insan ihtiyaçları ve davranışların kendini belirlemesi. Psikolojik Sorgulama, 11(4), 227-269. https://doi.org/10.1207/S15327965PLI1104_01

Deci, E., \& Ryan, R. (2002). Kendini belirleme teorisi. Retrieved from http://psych.rochester.edu/SDT/theory.html; erişimtarihi15.07.2016

Deci, E., Ryan, R., Gagne, M., Lronr, D., Usunov, J., \& Kornazheva, B. (2001). Eski bir doğu bloğu ülkesinin çalışma organizasyonlarında memnuniyet, motivasyon ve refahı isteyin: kültürler arası bir kendini belirleme 
çalışması. Kişilik ve Sosyal Psikoloji Bülteni, 27(8), 930-942. https://doi.org/10.1177/0146167201278002

Diener, E. (1984). Öznel refah. Psikolojik Bülten, 95, 542-575. https://doi.org/10.1037//0033-2909.95.3.542

Diener, E., Emmons, R., Larsen, R. J., \& Griffin, S. (1985). Yaşam ölçeği ile memnuniyet Kişilik Değerlendirme Dergisi. Journal of Personality Assessment, 49(19), 71-75. https://doi.org/10.1207/s15327752jpa4901_13

Engür, M. (2011). Performans başarısızlı̆̆ değerlendirme envanterinin (PFAI) ve kendi kendine konuşma anketinin (S-TQ) Türk sporcu popülasyonuna uyarlanması ve uygulanması. Yayımlanmamış doktora tezi. İzmir, Türkiye: Ege Üniversitesi.

Gall, J., Gall, M., \& Borg, W. (1999). Eğitim araştırması uygulaması. New York: Longman.

Gay, L. (1987). Analiz ve uygulama için eğitim araşstırma yeterlikleri. New York: Macmillan Yayınevi.

Gould, D., Damarjian, N., \& Greenleaf, C. (2002). En yüksek performans için görüntü eğitimi. In J. Van Raalte \& B. Brewer (Eds.), De spor ve egzersiz psikolojisini araşttrtyorlar (2nd ed.). Washington, DC: Amerikan Psikologlar Birliği.

Gould, D., Eklund, R., \& Jackson, S. (1992). 1988 ABD Olimpiyat güreşi mükemmellik: 2. düşünce ve yarışma sırasında ortaya çıkan etkileri. Spor Psikoloğu, 6, 383-402. https://doi.org/10.1123/tsp.6.4.383

Han, J., \& Kim, S. (2004). Kore'de kırsal alanda yaşlı kadın ve erkeklerin demografik değişkenleri ve benlik saygısının yaşam doyumu üzerindeki etkisi. Yaşlılar için Refah Dergisi, 26, 92-118.

Hanton, S., \& Jones, G. (1999): Multimodal bir müdahale programının sanatçılar üzerindeki etkileri: 2. kelebeklerin oluşum halinde uçmaları için eğitilmesi. Spor Psikoloğu, 13, 22-41. https://doi.org/10.1123/tsp.13.1.22

Hardy, J. (2006). Açıkça konuşma: Kendi kendine edebiyatın eleştirel bir incelemesi. Spor ve Egzersiz Psikolojisi, 7, 81-97. https://doi.org/10.1016/j.psychsport.2005.04.002

Hardy, J., \& Hall, C. (2005). Self-Talk Kullanım Anketini kullanarak test-tekrar test güvenirliklerinin karşılaştırılması. Spor Davranışı Dergisi, 28(3), 201-215. https://doi.org/10.1037/t70752-000

Hardy, J., Hall, C., \& Hardy, L. (2005). Ölçme sporcusu kendi kendine konuşma. Spor Bilimleri Dergisi, 23(9), 905-917. https://doi.org/10.1080/02640410500130706

Kim, M. (1982). Korece'deki yaşlıların yaşam memnuniyeti. Kore Kore İktisat Derneği Dergisi, 29(3), 45-54.

Köker, S. (1991). Normal ve anormal ergenler arasındaki yaşam doyumu. Yayımlanmamış Matser Tezi. Ankara, Türkiye: Ankara Üniversitesi.

Morrin A. (1993). Kendi kendine konuşma ve öz farkındalık: ilişkinin niteliği hakkında. Zihin ve Davranış Dergisi, 14(3), 223.

Nergiz, S., Bayköse, N., \& Yildiz, M. (2015). Kendi kendine konuşma: Modern ve halk dansları arasındaki kendi kendine konuşma durumu. Niğde Üniversitesi Beden Eğitimi ve Spor Bilimleri Dergisi, 9(Özel say1), 40-49.

Oyun, K., Hardy, J., \& Hall, C. (2001). Egzersizde kendi kendine konuşma açıklaması. Spor ve Egzersiz Psikolojisi, 2, 233-247. https://doi.org/10.1016/S1469-0292(01)00011-5

Pavot, W., Diener, E., Colvin, C., \& Sandvik, E. (1991). Yaşam Ölçeği ile Memnuniyetin İleri Doğrulanması: Refah ölçütlerinin çapraz yöntem yaklaşımı için kanıt. Kişilik Değerlendirme Dergisi, 57, 149-161. https://doi.org/10.1207/s15327752jpa5701_17

Tavsancil, E. (2002). Measurement of attitudes and data analyses with SPSS (1st ed.). Ankara: Nobel Yayın Dağıtım.

Thelwell, R., \& Maynard, I. (2003). Bir zihinsel beceri paketinin kriketçilerde 'tekrarlanabilir iyi performans' üzerindeki etkisi. Spor ve Egzersiz Psikolojisi, 4, 377-396. https://doi.org/10.1016/S1469-0292(02)00036-5

Williams, G., Frankel, B., Campbell, D., \& Deci, E. (2000). Rochesterbiyopsikososyal programdan ilişki merkezli bakım ve sağlı sonuçları üzerine araştırma: kendi kendini belirleyen bir teori entegrasyonu. Ortak Aile Sağglı̆̆ Dergisi, 18(1), 79-91. https://doi.org/10.1037/h0091854

Yildiz, A., Gulsen, D., \& Yilmaz, B. (2015). Sporcuların akış durumunun yaşam doyumuna etkisi. Niğde Üniversitesi Beden Eğitimi ve Spor Bilimleri Dergisi, 9(Özel Say1), 58-64.

Zervas, Y., Stavrou, N., \& Psychountaki, M. (2007). Spor İçin Kendi Kendine Konuşan Anketin (S-Tq) geliştirilmesi ve doğrulanması. Uygulamall Spor Psikolojisi Dergisi, 19, 142-159. https://doi.org/10.1080/10413200601185156 


\section{Copyrights}

Copyright for this article is retained by the author, with first publication rights granted to the journal.

This is an open-access article distributed under the terms and conditions of the Creative Commons Attribution license (http://creativecommons.org/licenses/by/4.0/). 